\title{
Conflicting Social Perceptions of Men Who Teach in Indonesian Kindergartens
}

\author{
Hani Yulindrasari \\ Universitas Pendidikan Indonesia, Indonesia \\ The University of Melbourne, Australia \\ Corresponding e-mail: haniyulindra@upi.edu
}

\begin{abstract}
This paper aims to understand social expectations of male teachers who work as educators and carers of young children. According to the Ministry of Education and Culture's Centre of Data and Statistics of Education/PDSP (2014), the number of male teachers in Indonesian ECE is very small; it is only 3\% $(11,434)$ of the whole population of ECE teachers $(377,164)$. However, the number of male teachers has increased compared to the 2001 data, which only $1.95 \%$ of teachers in ECE were males. There is an assumption that the small number of men teaching in ECE is related to heteronormative gender ideology of the society. Caring for and educating children is considered a female role while providing for and protecting the family is the male's domain. The increasing number of male teachers in Indonesia might be a clue of as to a shift in the Indonesian idealized gender construction. Based on interviews with seven parents, seven female teachers, and four school administrators, this paper argues that there are conflicting social perceptions of men who work in kindergartens. In a situation where ideologically men/women supposed to be superior to women/men, the society perceives male teacher in accordantly. The attempt to perceive as socially expected trigger inconsistency, contradictions, and ambivalence. The analysis shows that the contradiction is embedded within the social gender system itself. Thus, social perceptions of male teachers in ECE is not a simple black and white social phenomena.
\end{abstract}

Keywords: Indonesian kindergarten, gender, male teachers

\section{INTRODUCTION}

Early Childhood Education (ECE) has always been dominated by women (Akman, Taskin, Ozden, Okyay, \& Cortu, 2014; Sargent, 2005; Sumsion, 1999). Historically, local kindergarten in Indonesia was established by a Islamic women organization, Aisyiah, in 1919 in Yogyakarta (Muhammadyah, 2014). Then in 1922, Ki Hajar Dewantara, the "father of Indonesian education", established Taman Indriya, an Indonesian translation of kindergarten, also in Yogyakarta. Dewantara (1961) believed that women are the first and foremost educator for young children. He connected it with women's "natural capacities" of softness, magnanimity, beauty, purity and justices are best to educate children.

Gender assumption embedded in the discourses and practices of ECE arguably would influence men decision on whether or not to work in the field, also employers on whether or not to employ men as teachers. A small scale study by Suyatno (2004) indicates that there is a negative stigma attached to men who work in ECE. The stigma comes from the dominant gender stereotypes that place men as outsider in the field of child education.

However, in the last fifteen years, Indonesia experiences a slow increase of male teachers in kindergarten. The number of male teacher in ECE is rising, from only $1.95 \%$ in 2001 to around $3 \%$ of teachers in 2014. This increase is a clue to a growing interest of men working in ECE. The increase could also mean that ECE is moving toward a transformation of gender stereotypes in the society, as (Segal, 2007) argues that a change in one category of sex would affect the other.

This paper investigates contemporary gender stereotypes in Indonesian urban society reflected through social perceptions and expectations of male teachers who work in ECE. This paper starts with a short overview of gender construction in Indonesia. It will be followed by an explanation of research method and then the finding will be discussed. 
Throughout this paper, I argue that there are conflicting social perceptions of male teachers in Kindergarten. The ambivalent perceptions show that Indonesian conventional gender constructions, like any other cultural system, 'embody contradictions and ambiguities' (Suzanne A Brenner, 1995, p. 41).

\section{GENDER AND MALE TEACHERS IN INDONESIA}

Gender constructions in Indonesia are not singular since there are more than 300 ethnic groups with different cultures and social structures. However, the New Order regime homogenized and sanctioned Indonesian gender constructions through the Law No.1 /1974 on Marriage (Robinson, 2000). In this paper, I refer the New Order gender construction as a conventional gender ideology. The law is still effective to this day. The idea of kodrat influences the Law. Kodrat is fixed and innate characteristics of God's creatures which include physical and psychological quality and roles (Dewantara, 1961; Yafie, 1999), and Javanese ideology (Suzanne April Brenner, 1998; Setyawan, 2007; Wichelen, 2009). Kodrat organised gender based on the 'different but complementary' discourse. The different but complementary discourse put men and women in an oppositional position (Bourdieu, 2001). Within this discourse, men belong to external world, public, visible, high; while women belong to the opposite: internal, private, and invisible (Bourdieu, 2001). The Law prescribed the husband as the leader, breadwinner and protector of the family and the wife as homemaker and household manager (The Republic of Indonesia, 1974). Within the New Order's gender construction, children education and care were included in the five keys of Indonesian women's duty to the nation (Sunindyo, 1995).

Since the fall of Suharto in 1998, the state's gender construction has been contested. Thus Indonesian gender ideologies become more fluid and diverse (Yulindrasari \& McGregor, 2011). The gender mainstreaming initiatives, women's rights NGO activism, the rise of Islamic modernist movements, and also the emergence of male feminist initiatives have shaken the state's construction of gender. Women's involvement in public sectors including in politics has improved. There are eight female ministers in the current Joko Widodo's administration. The ministries are not restricted to only traditionally female domain such as, social affairs, health, and women empowerment, but also include strategic ministry such as the Ministry of Finance, the Ministry of Foreign Affairs and the Ministry of Marine and Fisheries. Men's roles are also extended, from only breadwinner and the head of the family to be a super dad who involve actively in child rearing and education (Bemmelen, 2016; Yulindrasari \& McGregor, 2011).

Despite the progressive transformation, there is surprisingly little research on men's participations in non-traditional occupation such as kindergarten teaching in Indonesian context. Male teacher is only briefly mentioned in Suyatno's (2004) research about gender mainstreaming in kindergarten. $\mathrm{He}$ mentioned it in relation to gender balance in the ECE workforce. Suyatno's study gives a clue about the social stigma attached to a man who teach in kindergarten. However, no further analysis is provided. Another accessible research about male teachers in Indonesia is a master thesis in Universitas Pendidikan Indonesia by Yunita (2016). Her thesis focuses more on male teacher's teaching styles eith no comparison to their female counterparts. Based on interviews with three male teachers in two different kindergarten, she describes male teachers' assumptions of why there is only a few men interested to work in ECE and sums up their reasons of teaching in kindergarten. Her respondents confirmed that low salary and ECE as being stereotypically female world are some of the factors hindering men to work in ECE (Yunita, 2016). Both studies are lacking further analysis on the social perceptions that both studies argue to be the obstacle of men working in ECE. This study tries to fill in the gap by investigating how parents, female teachers, and school's administrators perceive men who teach in kindergarten.

\section{METHODS}

This study uses qualitative approach with in depth interview as its main method of data collection. The primary data comes from eighteen audio recorded semi-structured interviews with seven parents, seven interviews with female colleagues, and seven interviews with school's administrators in four different schools in Bandung and Yogyakarta. The study uses convenience sampling method which relies on the most accessible sample (Berg, 2004). I used my personal contacts with the Indonesia Kindergarten Teacher Association (IGTKI) and Indonesia Early Childhood Education Association (HIMPAUDI) to identify prospective participants.

Every participant has an experience of having male teachers in her/his child class or working with male teachers in ECE setting. Before the interview, each participant's consent was sighted and secured. The interviews focus on their perceptions of and 
expectations on men who teach young children in kindergartens.

The recorded interviews were transcribed, and the data were treated as text. The study then utilized a hermeneutic interpretative

Approach to draw the meaning of the participants' narratives about male teachers.

\section{FINDINGS}

Participants in this study show positive perceptions of male teachers' involvement in ECE. What I mean by positive here is that they are not resistant to men working in ECE. However, conventional gender stereotypes still the fundamental reason for their acceptance is still informed by conventional gender stereotypical beliefs and norms. They employ classic oppositional discourses such as reasons versus emotions, nurturing ability versus physical ability, and multitasking versus single tasking to highlight male and female teacher differences. Most of them still believe in gender essentialism. However, they also believe in gender as a product of learning. On the one hand, they essentialise nurturing competence, rationality, emotional stability, and physical strength. On the other hand, gender is learnt and situated when they talked about men in an ideologically female domain.

\subsection{Nurturing Competence}

Nurturing competence is the most important aspect in teaching your children. There are two basic assumption come up in the analysis related to nurturing competence of teachers. First assumption is that women are the best for educating children, simply because ideologically women have innate capacity to care for children.

Nurturing is naluri perempuan (women's instinct). Women have jiwa keibuan (motherly soul), more telaten (patience and detail) because Bapak (Father) is tulang punggung (the protector and provider of the family. So ... yea ... maybe women are the best to teach in kindergarten (interview with Erny, 30 October 2014)

Erny's comment is very typical in this study. Her comment support gender essentialism embedded in the discourse of kodrat and Ki Hadjar Dewantara's concept of ECE. It indicates that the assumption of ECE as an extension of mother's care at home (Dewantara, 1961; Sargent, 2004).
The second assumption is that nurturing is challenging for men because it is simply not natural for them. However, men can acquire nurturing competence by learning. Once a man masters the competence, he should be highly appreciated. The comment below describes the perception.

I once worked with a male teacher. He likes to cuddle. I asked him "How did he learn that?" He said "Nothing; it's just came naturally to me" From the outside, he looks slenge'an. I didn't believe that he could do it. Being able to take care of 12 children in one class is amazing, two thumbs up for him (Interview with Rosy, a parent, 24 October 2014)

The word slenge'an is a slang word means relaxed and clumsy. Being relaxed and clumsy is associated with lack of ability to be responsible. Teaching young children, since it is associated with parental role at home, is full of responsibility. The use of word slenge'an in the above comment is not only aiming at the relaxed and clumsy characteristic but also at men as a gender category. Rosy doubts nurturing ability in men, because it is unnatural for them. Men need to learn how to handle a child. Because it is not natural for them, once they know how to do it and good at it, men deserve high appreciation.

\subsection{Emotional Competence}

A Kantian discourse of reasons/rationality versus emotionality (Seidler, 1997) emerges from the data. Men are assumed to be emotionally more stable than women. Thus, men are expected to play the role of mood balancer in the classroom. One of the participants links women's emotionality with female biology (Shields, 2013). Her comment was,

Believe it or not, every woman has a monthly cycle that influences her emotions and mood stability. To me, men seem to be able to maintain their mood consistently. So ... male teachers can be mood balancers. (Interview with Dian, a school principal, 10 October 2014)

The comment is influenced more by gender stereotypes than by scientific facts. The physiological reason have classically used to justify and legitimate lack in women that leads to the perception of women's inferiority to men (Nicholson, 1999). Despite the fact that there is insufficient evidence to conclude any correlation between emotion and mood regulation in women during their menstrual cycle (Romans, Clarkson, 
Einstein, Petrovic, \& Stewart, 2012). Dian's comment consistent with Shield's argument (2013) that gender beliefs and stereotypes significantly influence the way an individual interprets his/her own and other's emotional behaviour. Dian's comment also influenced by Javanese-Indonesian gender ideology which states that men have better self-control over their emotions and behaviors (Suzanne A Brenner, 1995). Thus, it is unsurprising that the participant attributes cognitive emotioncontrol to men and a difficulty in maintaining emotion consistency to women (Zammuner, 2000).

In another part of the interview, when I asked her about different nurturing competence between male and female teacher, Dian contradicted herself by saying,

Male teachers usually cannot stand stubborn children; they are not as patient as women. Their emotion is easily provoked, I can see when their emotion start to go up, I can see that they are angry ... they are indeed not as patient as women. (Interview with Dian, 10 October 2014)

Dian's comment is very typical among participants in the study. The comment reproduces stereotypical beliefs about women versus men nurturing ability. When it is situated within nurturing ability, men have poorer emotional competence than women. On the contrary, when it is framed within ideological rationality, men's emotional competence is better than women's.

\subsection{The Physicality}

The assumption of gender as natural raises expectation for male teachers to work in accordance with their gender normative roles (see Mills, Haase, \& Charlton, 2008; Murray, 1996; Sumsion, 2000). The idea of men as physically stronger, active, and mobile than women is often seen as one of the benefits of having male teacher in ECE (Sargent, 2005). Male teachers are expected to be able to perform some part of dominant construction of masculinity, such as doing physical labour (Mills et al., 2008). Similar expectation was mentioned by Dian, a school principal,

I can't imagine a female teacher climbing a ladder! That is why we prioritize male teachers. There was a time when we only had one male teacher, poor him, there was too much to handle. We need male teachers to deal with equipment, electricity, decoration, and also working late, even though we (female teachers) also work late if needed, we feel safer when there are male teachers around. (Interview with Dian, 10 October 2014)

The above comment shows the visibility of male body in a female dominated field. Dian's association of male body with physical strenght and technical skills mirrors 'gendered embodiment' (Williams, Weinberg, \& Rosenberger, 2013, p. 720). According to Butler's (2004) embodiment designates a set of societal norms. The comment reflects bodily societal norms that prescribe women are weak and vulnerable and men are strong and protecting.

The visibility of male body is also echoed in the social expectation of male teachers being role models for boys. The comment below illustrates the expectation.

Yea male teacher could show how to be a man..., (so the boy would think) I am a man, I have to be firm like Mr. Al...If I want to be a police man I have to be like Mr. Al...not the Miss (female teacher). (Interview with Kiky, a parent, 30 October 2014)

Kiki's comment implies an assumption that a material body would naturally perform accordingly to the societal norms. A male body is expected to possess masculine characteristics or 'doing gender' (West \& Zimmerman, 1987, p. 126) accordingly to social expectations. On the contrary, the comment also suggests that gender is learnt and acquired. Boys need to be taught how to be boys, a perception that is contradictory to the notion of kodrat (gender as natural).

\subsection{Contesting Kodrat}

Not all participants still believe in the idea of kodrat. Three of the participants from the same school believe that gender is detached from sex. They believe that masculine and feminine traits could be possessed by both male and female. Below is one of their comments.

Men and women are the same, what we are looking for is someone who loves children and loves learning, that's all. It doesn't matter male or female. However, our gender awareness has helped us to understand that men are usually not trained enough for this (child care and education), we are aware of this. We understand that feminine or masculine is not attached to the sexed bodies. In many things I have more masculine characteristics than Uncle Jaja that is something we should celebrate. (Ms. Ana, female school's owner, Saturday, 29 November 2014) 
Ana's comment shows understanding of gender as a social construction and something that is learnt instead of naturally possessed. Ana's and the other two's perception, however, is not common among other participants. Their background as a gender, democracy, and pluralism activist allows her to think more progressively about gender. Ana's perception about gender has led her to employ seven male teachers in her school.

\section{CONCLUSION}

This study reveals that binary constructions of gender are embedded in the participants' perceptions of men who teach in ECE. The discourse of gender as natural, rooted in the notion of kodrat, interferes the way the participants perceive male teachers especially concerning their nurturing ability, emotional competence, and physicality. The perceptions and expectations are consistent to the conventional gender ideology. However, the study also shows that there is a light in the understanding of gender as a product of culture and socialization. Even though the conventional gender ideology still takes part in the contradictory perceptions, it shows that cultural system, including gender, inherits contradictions and ambiguities that is why every social phenomena is complex (Brenner, 1998), so does the social perception of men who work in kindergartens/ECEs.

\section{ACKNOWLEDGEMENTS}

This paper is a small part of a chapter in an ongoing Ph.D. thesis of the author supervised by Dr. Kalissa Alexeyeff and A/Prof Katharine McGregor at the University of Melbourne, Australia. The working title of the thesis is 'Negotiating Masculinities: Lived Experiences of Male Teachers in Indonesian ECE'. The thesis is projected to be completed in 2017. The author is sponsored by Beasiswa Luar Negeri Direktorat Pendidikan Tinggi (DGHE scholarship) from the Ministry of Research, Technology and Higher Education of the Republic of Indonesia.

\section{REFERENCES}

Akman, B., Taskin, N., Ozden, Z., Okyay, O., \& Cortu, F. (2014). Parents' views on the appointment of male teachers in Turkish preschools. Education as Change, 18(1), 21-32. doi: 10.1080/16823206.2013.847009
Bemmelen, S. T. v. (2016). State of the World's Fathers Country Report: Indonesia 2015 (P. M. Team, Trans.). In M. Soesman \& S. D. Noya (Eds.). Jakarta: Rutgers WPF Indonesia.

Berg, B. L. (2004). Qualitative Research Methods for the Social Science. Boston: Allyn and Bacon.

Bourdieu, P. (2001). Masculine Domination (R. Nice, Trans.). Stanford: Stanford University Press.

Brenner, S. A. (1995). Why Women Rule the Roost: Rethinking Javanese Ideologies of Gender and Self-Control. In A. Ong \& M. G. Peletz (Eds.), Bewitching women, pious men: gender and body olitics in Southeast Asia (pp. 19-50). Berkeler and Los Angeles: Univesity of California Press.

Brenner, S. A. (1998). The Domestication of Desire: Women, Wealth, and Modernity in Java. Princeton: Princeton University Press.

Butler, J. (2004). Undoing Gender. London: Routledge.

Dewantara, K. H. (1961). Soal Wanita. Yogyakarta: Majelis Luhur Taman Siswa.

Mills, M., Haase, M., \& Charlton, E. (2008). Being the 'right' kind of male teacher: the disciplining of John. Pedagogy, Culture \& Scoiety, 16(1), 71-84.

Muhammadyah. (2014). Aisyiyah: Mencetak Jejak Sejarah. Retrieved 6 February 2014, from http://www.muhammadiyah.or.id/content-199det-aisyiyah.html

Murray, S. B. (1996). "We All Love Charles": Men in Child Care and the Social Construction of Gender. Gender and Society, 10(4), 368-385. doi: 10.2307/189677

Nicholson, P. (1999). Controlling the gendered body. Psychology, Evolution, and Gender, 1(2), 101-105.

Robinson, K. (2000). Indonesian Women: From Orde Baru to Reformasi. In L. P. Edwards \& M. Roces (Eds.), Women in Asia: Tradition, Modernity, and Globalisation (pp. 139-169). St. Leonard: Allen \& Unwin.

Romans, S., Clarkson, R., Einstein, G., Petrovic, M., $\&$ Stewart, D. (2012). Mood and the Menstrual Cycle: A Review of Prospective Data Studies. Gender Medicine(5), 361. doi: 10.1016/j.genm.2012.07.003

Sargent, P. (2004). Between a Rock and a Hard Place: Men Caught in the Gender Bind of Early Childhood Education. The Journal of Men's Studies, 12(3), 173-192. 
Sargent, P. (2005). The Gendering of Men in Early Childhood Education. Sex Roles, 52(3/4), 251259. doi: 10.1007/s11199-005-1300-x

Segal, L. (2007). Slow Motion: Changing Masculinities, Changing Men (Third, revised edition ed.). New York: Palgrave Macmillan.

Seidler, V. J. (1997). Man Enough: Embodying Masculinities. London: Sage Publication.

Setyawan, Y. B. (2007). "Be Subject to Your Husband as You are to the Lord" in Ephesians 5;21-33 - Illuminated by an Indonesian (Javanese). Asia Journal of Theology, 21(1), 50-68.

Shields, S. A. (2013). Gender and Emotion: What We Think We Know, What We Need to Know, and Why It Matters. Psychology of Women Quarterly, 37(4), 423-435. doi: $10.1177 / 0361684313502312$

Sumsion, J. (1999). Critical Reflections on the Experiences of a Male Early Childhood Worker. Gender and Education, 11(4), 455468.

Sumsion, J. (2000). Negotiating Otherness: a male early childhood educator's gender positioning. International Journal of Early Years Education, 8(2), 129-140. doi: 10.1080/09669760050046174

Sunindyo, S. (1995). Gender Discourses on Television. In V. Hooker (Ed.), Culture and Society in New Order Indonesia (pp. 134-148). Oxford, UK: Oxford University Press.

Suyatno. (2004). Analisis Kesenjangan Jender pada Aspek Kebijakan, Kurikulum, dan Sumberdaya Manusia pada Pendidikan Taman KanakKanak (TK) Studi di Kota Semarang - Jawa Tengah [Analysis of gender gap in policy, curriculum, and human resoource in Kindergarten: a study in Semarang, Central Java]: Pusat Penelitian Gender/PSW, Universitas Diponegoro Semarang.

The Republic of Indonesia Law No 1/1974 about Marriage, 1/1974 C.F.R. (1974).

West, C., \& Zimmerman, D. H. (1987). Doing Gender. Gender \& Society, 1(2), 125-151.

Wichelen, S. v. (2009). Polygamy Talk and the Politics of Feminism: Contestations over Masculinity in the New Muslim Indonesia. Journal of International Women's Studies, 11(1), 173-188.

Williams, C. J., Weinberg, M. S., \& Rosenberger, J. G. (2013). Trans Men: Embodiments, Identities, and Sexualities. Sociological Forum, 28(4), 719-741.
Yafie, K. H. A. (1999). Kodrat, Kedudukan, dan Kepemimpinan Perempuan. In L. Z. Munir (Ed.), Memposisikan Kodrat: Perempuan dan Perubahan Dalam Perspektif Islam. Bandung: Mizan.

Yulindrasari, H., \& McGregor, K. (2011). Contemporary discourses of motherhood and fatherhood in Ayahbunda, a middle-class Indonesian parenting magazine. Marriage \& Family Review(5), 605. doi: 10.1080/01494929.2011.619304

Yunita. (2016). Gaya Mengajar Guru Laki-Laki di Taman Kanak Kanak (Teaching Styles of Male Teacher in Kindergarten). (Master of Education), Universitas Pendidikan Indonesia, Bandung.

Zammuner, V. L. (2000). Men's and women;s lay theories of emotion. In A. H. Fischer (Ed.), Gender and Emotion: Social Psychological Perspectives (pp. 48-70). Cambridge: Cambridge University Press. 